\title{
AFTER THE HITTITES: THE KINGDOMS OF KARKAMISH AND PALISTIN IN NORTHERN SYRIA
}

\section{MARK WEEDEN}

\author{
Introduction: deconstructing the 'sea-peoples'
}

During the twelfth century BC numerous large-scale, palace-centred, and/or imperial stateformations either apparently disappeared, or transformed into other political entities, or are supposed to have experienced significant contraction: the Hittite Empire, the palace centres of Mycenaean Greece, Egypt's empire in the Levant, Assyria, and Babylonia, although the last two were less radically affected. ${ }^{1}$ The western contours of this collapse (Levant and Anatolia) are frequently associated, whether as symptom or cause, with the rise to prominence of various peoples and social formations partially subsumed under the misleading term 'sea-peoples'. ${ }^{2}$ The following historical period is frequently referred to as a Dark Age because of the apparent lack of written sources throughout the eastern Mediterranean, at least by contrast with the abundant documents of the periods before and after; it is roughly coterminous with the archaeological period of the Early Iron Age (c. 1200-900 BC, also Iron Age I). But new excavations, new finds of inscriptions written in Hieroglyphic Luwian, and an improved understanding of previously available ones, are profoundly changing our image of the North Syrian region west of the Euphrates, which had been dominated by the Hittite empire for the previous roughly 150 years. ${ }^{3}$

Hieroglyphic Luwian refers to the script (Anatolian Hieroglyphs) and the language (Luwian, a language closely related to Hittite) which are used on Iron Age, i.e. post-1200 $\mathrm{BC}$, inscriptions written according to iconographic and rhetorical norms which largely

\footnotetext{
${ }^{1}$ See e.g. W. A. Ward and M. Joukowsky, ed., The crisis years: the 12th century BC from Danube to the Tigris (Providence 1992); R. Drews, The end of the Bronze Age: changes in warfare and the catastrophe ca. 1200 (Princeton 1995); C. Bachhuber and R. G. Roberts, ed., Forces of transformation: the end of the Bronze Age in the Mediterranean (Oxford 2009); C. M. Monroe, Trade, tradition, and transformation in the eastern Mediterranean ca. 1350-1175 BCE (Münster 2009); K. Strobel, ed., Empires after the Empire: Anatolia, Syria and Assyria after Suppiluliuma II (ca. 1200-800/700 B.C.), Eothen 17 (Firenze 2011); K. Aslihan Yener, ed., Across the border: late Bronze-Iron Age relations between Syria and Anatolia (Leuven 2013).

${ }^{2}$ E.g. N. K. Sandars, The sea peoples. Warriors of the ancient Mediterranean 1250-1150 BC (London 1978); E. Oren, ed., The sea peoples and their world: a reassessment (Philadelphia 2000); T. Harrison, ed., Cyprus, the sea-peoples and the eastern Mediterranean: regional perspectives of continuity and change, Scripta Mediterranea 27-28 (2006-2007; Toronto 2008); A. E. Killebrew and G. Lehmann, ed., The Philistines and other 'sea peoples' in text and archaeology (Atlanta 2013).

${ }^{3}$ E.g. T. P. Harrison, 'Neo-Hittites in the land of "Palistin". Renewed investigations at Tell Ta'yinat on the plain of Antioch', Near Eastern Archaeology 72/4 (2009), 174-89; N. Marchetti, 'Karkemish on the Euphrates: excavating a city's history', Near Eastern Archaeology 75/3 (2012), 132-47; K. Kohlmeyer, 'Building activities and architectural decoration in the $11^{\text {th }}$ Century BC. The temples of Taita, king of Padasatini/Palistin in Aleppo and 'Ain Dārà', in Strobel, Empires (n. 1 above) 255-80.
}

BICS-56-2 - 2013 
continue the cultural legacy of the Late Bronze Age Hittite Empire (c. 1450-1200 BC). ${ }^{4}$ The script had its origins probably some time in the seventeenth to fifteenth centuries $\mathrm{BC}$, and was at first only used on seals for short marks of identity or iconic-symbolic uses including signs associated with 'goodness' or 'life'. It was developed into a writing system for extended royal inscriptions on stone exclusively in the Luwian language during the fourteenth to thirteenth centuries BC. With the exception of its use in sealing, it continued to be used in this way down to the end of the eighth century BC, although it was also used for economic documents and letters, as shown by a small number of lead strips from the eighth century. ${ }^{5}$ Although the number of inscriptions from this period is small, albeit growing, the continued use of Luwian provides significant evidence for cultural continuities in the Early Iron Age.

Written sources, however, are neither the only nor the main materials providing data for the debates concerning this period. A large part of the controversy is archaeological, in particular concerned with archaeology's ability or lack thereof to detect migration on the basis of pottery alone. This is compounded by the difficulties inherent in quantifying and explaining massive social change in ancient societies more generally. Are we dealing with a drastic break in the forms of social life over a huge area from central Anatolia to southern Palestine, or do elements of continuity from the past rather define the new world that was growing out of the old? ${ }^{6}$ Here at the cusp from the Bronze to the Iron Age in one of the most important areas for an understanding of the genesis of the world we live in today, we are still grasping in the darkness when we try to explain what was actually happening.

The conventional version of events concerning the end of the Late Bronze Age relies heavily on a combination of various different types of evidence: ${ }^{7}$ Egyptian inscriptions and reliefs concerning 'sea-peoples' including a group called the $p w-r-s 3-t j$ (commonly vocalized as peleset, in older literature as pulasati), particularly from the reign of Ramesses III; the appearance of the Biblical Philistines in Palestine; the spread of locally made Mycenaean-style pottery along the coastal strip from southern Anatolia down to Gaza,

\footnotetext{
${ }^{4}$ J. D. Hawkins, Corpus of Hieroglyphic Luwian inscriptions vol. I.1-3: inscriptions of the Iron Age (Berlin 2000); A. Payne, Iron Age Hieroglyphic Luwian inscriptions, SBL Writings from the Ancient World 29 (Atlanta 2012).

${ }^{5}$ Hawkins, Corpus vol. I.2 (n. 4 above) 533-55.

${ }^{6}$ For a critique of this question in terms of the opposing camps of research ideology relating to this period see I. Singer, 'The Philistines in the north and the kingdom of Taita', in The ancient Near East in the $12^{\text {th }}$ to $10^{\text {th }}$ centuries BCE: culture and history. Proceedings of the international conference held at the University of Haifa, 2-5 May, 2010, ed. G. Galil, A. Gilboa, A. M. Maeir and D. Kahn, Alter Orient und Altes Testament 392 (Münster 2012), 451-56.

${ }^{7}$ For the classic statements of this historical paradigm see G. Maspero, The struggle of the nations: Egypt, Syria and Assyria, ed. A. H. Sayce, trans. M. L. McClure, History of the Ancient Peoples of the Classic East 2 (New York 1896) 462-587; W. F. Albright, The archaeology of Palestine and the Bible (New York 1932); A. Alt, 'Ägyptische Tempel in Palästina und die Landnahme der Philister', Zeitschrift des Deutschen Palästina-Vereins 67, 1-20. For a deconstruction of said paradigm see I. Finkelstein, 'Is the Philistine paradigm still viable?', in The synchronisation of civilizations in the eastern Mediterranean in the second millennium BC. III, ed. M. Bietak and E. Czerny, Contributions to a Chronology of the Eastern Mediterranean 9, Oesterreichische Akademie der Wissenschaften: Denkschriften der Gesamtakademie 37 (Vienna 2007) 517-24.
} 
paralleled by similar developments in Cyprus; and the destruction of multiple palatial sites in the same area. ${ }^{8}$

Numerous phenomena are associated with this basic scheme and its multiple variations: the allegedly Greek names of some of the later Biblical Philistines and a supposedly Greek origin of some Philistine concepts, both of which are debatable; ${ }^{9}$ the spread of new types of cylindrical loom-weights and circular hearth-types in roughly the same areas as the Mycenaean-style pottery; ${ }^{10}$ the prioritization of military techniques based on infantry warfare. ${ }^{11}$ This is not to mention the endless attempts to connect the different types of helmets, cuirasses, boats, and carts depicted on Egyptian reliefs associated with the 'seapeoples' with those depicted on Mycenaean-style pottery and in other media from around the Mediterranean. ${ }^{12}$ The urge to put a name to these various 'peoples' and identify where they came from is common, although it is not agreed that the ideology informing the Egyptian sources allows such neat categorizations, nor that the archaeological data referred to are necessarily an indication of large-scale ethnic migration.

It is in the inscriptions relating to years five and eight of the reign of Ramesses III (c. 1181 and $1178 \mathrm{BC}$ ) from his mortuary temple at Medinet Habu that the peleset (pw-r-s3$t / t j$ ) are first named as enemies in combination with associated groups. ${ }^{13}$ Although this is the first appearance of the peleset, Ramesses III appears to have otherwise partially imitated and borrowed from the lists of enemies in the earlier pharaoh Merneptah's inscriptions as well as

\footnotetext{
${ }^{8}$ Map of destroyed sites at Drews, End of Bronze Age (n. 1 above) Fig. 1. For a modification to Drews' map marking sites that were not destroyed after all see C. Bell, The evolution of long distance trading relationships across the LBA/Iron Age transition on the northern Levantine coast, BAR International Series 1574 (Oxford 2006) 137 (Map 1).

${ }^{9}$ For example T. Dothan, 'The "sea peoples" and the Philistines of ancient Palestine', in Civilizations of the ancient Near East vol. II, ed. J. M. Sasson (New York 1995) 1272; for Philistine names see F. Israel, 'Note di onomastica semitica 7/1. Rassegna critico-bibliografica ed epigrafica su alcune onomastiche palestinesi: Israele e Giuda, la regione filistea', Studi epigrafici e linguistici sul Vicino Oriente antico No. 8 (1991) 119-40; R. Zadok 'Philistian notes I'. Ugaritforschungen 41 (2009) 669-79. The number of 'Indo-European' or 'Greek' personal names beyond those from the later Persian period is in fact minimal. See further the 'Indo-European' Philistine name on an ostracon dated to the Iron IIA (tenth century BC) from Tell eș-Safi/Gath at A. M. Maeir, 'Insights on the Philistine culture and related issues. An overview of 15 years of work at Tell eș-Safi/Gath' in Ancient Near East, ed. Galil et alii (n. 6 above) 368 fig. 14. For further literature see A. M. Maeir, S. J. Wimmer, A. Zukerman, and A. Demsky, 'A Late Iron Age I/Early Iron Age II old Canaanite inscription from Tell eṣ-Ṣâfi/Gath, Israel: palaeography, dating and historical-cultural significance', BASO 341 (2008) 56-59.

${ }^{10}$ A. Yasur-Landau, The Philistines and Aegean migration at the end of the Late Bronze Age (Cambridge 2010) 234, 267.

${ }^{11}$ Drews, End of Bronze Age (n. 1 above).

${ }^{12}$ Recently, for example: R. G. Roberts, 'Identity, choice and the year 8 reliefs of Ramesses III at Medinet Habu', in Forces of transformation, ed. C. Bachhuber and R. G. Roberts (n. 1 above) 60-68; Yasur-Landau Aegean migration (n. 10 above); id., 'Chariots, spears and wagons: Anatolian and Aegean elements in the Medinet Habu land battle relief', in Ancient Near East, ed. Galil et alii (n. 1 above), 549-68.

${ }^{13}$ Inscription in the Second Court (year 5) peleset and tjekkeru; Inscription from the Second Pylon (year 8)

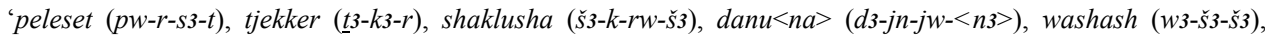
lands united'. Note in all the names the Egyptian phenomenon of 'Group Writing', meaning that each sound is spelled using a whole Egyptian word or particle. This is an additional hindrance to the interpretation of the phonetic readings. Text: K. A. Kitchen, Ramesside inscriptions: historical and biographical 5 (Oxford 1983) 25, 5; 40, 3-4; Trans.: K. A. Kitchen, Ramesside inscriptions 5: translations (Oxford 2008) 22, 34.
} 
in those of his illustrious namesake Ramesses II. ${ }^{14}$ Before they turned to Egypt Ramesses III tells us in his Year 8 inscription that the assorted groups laid waste to the Hittite capital Hattusa itself, as well as various major centres which are otherwise known to have been under Hittite control or influence, stretching from western Anatolia to Cyprus and northern Syria, including the Hittite administrative seat in northern Syria, Karkamish on the Euphrates. ${ }^{15}$ Although clearly a signal feature of royal victory discourse, the king succeeding where all the others failed, this narrative has laid the foundations for the way historians traditionally interpret the fall of the Hittite Empire. That the land-locked Hittite capital at Boğazköy/Hattusa in central Anatolia was destroyed by hostile intervention is not confirmed by more recent archaeological evidence concerning the demise of that city. It appears to have been evacuated for an unknown destination prior to its partial burning. ${ }^{16}$ However, Hittite cuneiform texts from the late thirteenth century BC also report sea-battles involving Cyprus/Alašiya from around their coastal domains. ${ }^{17}$

According to the same text, the invaders started out against Egypt from a temporary base in Amurru, a small Late Bronze Age kingdom in the Lebanon area. ${ }^{18}$ A further text on a papyrus detailing temple-donations from the time of Ramesses IV, but framed as a speech of Ramesses III, states that he brought two of the groups (sherden and washash) to Egypt, settled them in 'strongholds', and subjected them to tax. ${ }^{19}$ This has been construed as his having incorporated them as well as the associated peleset into the Egyptian imperial framework to man garrisons. ${ }^{20}$ Although now rejected by many scholars, the usual view has been to associate the appearance of Philistine cities in those parts of Palestine that had been part of the Egyptian empire with Ramesses III's resettlement policy. ${ }^{21}$

The peleset are the 'sea-peoples' group thought to be most readily identifiable, but efforts have been made to find traces of some of the others in texts from Ugarit dating to just after $1200^{22}$ and much later (eighth century) inscriptions from Cilicia. ${ }^{23}$ The spread of

\footnotetext{
${ }^{14}$ For this analysis see K. Strobel, 'The crucial $12^{\text {th }}$ Century BC: the "fall of empires" revisited', in Empires, ed. Strobel (n. 1 above) 184-96.

15 'No land could stand up against (before?) their arms, beginning from Hatti: Qode, Karkamish, Arzawa and Alasia cut off all at once in one place', Kitchen, Translations 5 (n. 13 above) 34.

${ }^{16}$ J. Seeher, 'Neue Befunde zur Endzeit von Hattuša: Ausgrabungen auf Büyükkaya in Boğazköy' in Acts of the IIIrd international congress of Hittitology, Çorum, September 16-22, 1996, ed. S. Alp and A. Süel (Ankara 1998), 515-23; H. Genz, "No land could stand before their arms, from Hatti .... on ..."? New light on the end of the Hittite Empire and the Early Iron Age in Central Anatolia' in Philistines, ed. Killebrew and Lehmann (n. 2 above) 469-77.

${ }^{17}$ For a summary of the textual evidence for the end of the Hittite Empire see I. Singer, 'New evidence on the end of the Hittite Empire', in Sea-peoples, ed. Oren (n. 2 above).

${ }^{18}$ Trans. K. Kitchen, Translations 5 (n. 13 above) 34.

19 Papyrus Harris §403. Trans. J. H. Breasted, Ancient records of Egypt, 5 vols (Chicago 1906) V, 201; P. Grandet, Le Papyrus Harris I (BM 9999), BE 109 (Cairo 1994).

${ }^{20}$ E.g. T. Dothan and M. Dothan, People of the sea: the search for the Philistines (New York 1992) 63.

${ }^{21}$ Finkelstein, 'Philistine paradigm' (n. 7 above) 517 for literature. See also D. Kahn, 'The campaign of Ramesses III against Philistia', Journal of Ancient Egyptian Interconnections 3-4 (2011) 1-11.

${ }^{22}$ RS 34.129 Letter from Hittite King to Prefect of Ugarit: W. Dietrich and O. Loretz, 'Das "Seefahrende Volk" von Šikila', Ugaritforschungen 10 (1978) 53-56. RS 20.238; RSL 1; J. Nougayrol in Ugaritica V, ed. C. Schaeffer (Paris 1968) 85-89.
} 
Mycenaean-style pottery across southern Turkey and the Levant has been held to offer confirmation of the hypothesis that a mass-migration brought entirely new peoples and cultures, mainly from the West, during this period. ${ }^{24}$ But some see the spread of Mycenaean-style pottery across the southern Levant in the early twelfth century $\mathrm{BC}$ as a phenomenon of elite imitation and cultural diffusion facilitated by the emergence of a vigorous, multi-ethnic, and mobile mercantile class centred on Cyprus towards the end of the Late Bronze Age. ${ }^{25}$ In their view, here was no unidirectional mass-migration - it was the pottery styles that moved, not the peoples associated with them. The 'peoples' mentioned in the Egyptian sources would then be ethnic constructs inspired by the repertoire of enemies otherwise found in Egyptian royal inscriptions. ${ }^{26}$ This approach has the advantage of placing archaeological artefacts within contexts of social use, rather than mapping them onto cultural carriers with specific ethnic identities, where these might have been constructed both by our sources and by ourselves.

However, recent study of the movement of 'foodways', i.e. methods of food preparation, cooking, and storage, cultural phenomena that do not have the same social cachet as eyecatching ceramic styles and are typically conservative, has led to a renewed emphasis on migration as an explanation for the spread of the pottery and a range of other artefacts and aspects of lifestyle. ${ }^{27}$ This approach takes the social and structural emphasis of the 'antimigrationist' perspective but uses it to different effect. In this view they are migrations that happened over a very long period, via various different routes, both on land and sea, and including multiple small-scale ethnic and economically defined groups engaging in a variety of either hostile or peaceful interaction with the local populations in the areas they came to. ${ }^{28}$ Various grades of this 'migration-lite' hypothesis with its differentiated approach to specific local phenomena can be found in the most recent archaeological literature, ${ }^{29}$ while the mass-migration model is also still vigorously defended. ${ }^{30}$

Whether or not the Egyptian designations in the texts of Ramesses III actually correspond to any otherwise attested ethnic or geographical names is unclear and in most cases highly speculative, especially given that the ethnonyms in the lists of enemies are part of the lens used to construct an Egyptian 'Feindbild'. Are the Egyptian inscriptions and reliefs describing specific peoples with ethnic identities, or do they point more to a way of

\footnotetext{
${ }^{23}$ KARATEPE $\S 2, \S 3, \S 58$; ÇİNEKÖY §1, §3; Hawkins, Corpus vol. I.1 (n. 5 above) 49, 56; Payne, Iron Age (n. 4 above) $21,34-35,43$. For recent summaries see Strobel, 'Crucial $12^{\text {th }}$ Century' (n. 14 above) 197-98 with n. 181; M. Gander, 'Abbiyawa - Hiyawa - Que: Gibt es Evidenz für die Anwesenheit von Griechen in Kilikien am Übergang von der Bronze- zur Eisenzeit?', SMEA 54 (2012), 282-89.

${ }^{24}$ E.g. Dothan, Sea-peoples (n. 9 above).

25 S. Sherratt, "Sea peoples" and the economic structure of the late second millennium in the eastern Mediterranean', in Mediterranean people in transition, ed. S. Gitin, A. Mazar, and E. Stern (Jerusalem 1998) 292-313. Also S. Sherratt 'The ceramic phenomenon of the "sea-peoples": an overview', in Philistines, ed. Killebrew and Lehmann (n. 3 above) 619-44.

${ }^{26}$ Strobel, 'Crucial $12^{\text {th }}$ century' (n. 14 above) 193-96.

${ }^{27}$ Yasur-Landau, Philistines (n. 10 above) passim.

${ }^{28}$ Yasur-Landau, Philistines (n. 10 above) 340-41.

${ }^{29}$ Maeir, 'Insights' (n. 9 above) 350-51.

${ }^{30}$ Singer, 'Philistines in the north' (n. 6 above).
} 
life on the fringes of the civilized world, rooted in mercantile mobility and small-scale adventurism? Are these specific groups involved in migration and/or colonization or are they more generally the type of people, peripheral groups destined by geography or status to commerce and its sister piracy, who would profit from a collapse of an international system based on centralized palace economies? The answer is frequently little more than a question of emphasis.

What is clear is that by the time written records are available again in any number, mainly in the form of the Neo-Assyrian royal annals from the ninth century BC onwards, the political landscape looks entirely different from what it had been at the end of the thirteenth century BC. Gone is the Hittite Empire and in its place southern Anatolia and northern Syria consist of a cluster of small states using the Luwian and Aramaic languages and employing hieroglyphic and alphabetic scripts respectively. It is here that a number of new documents both in hieroglyphic and cuneiform are beginning to fill the gaps at either end of this period.

\section{The end of the Hittite empire and continuity at Karkamish}

Most of the evidence for Early Iron Age Karkamish clusters in the twelfth and the tenth centuries BC, with an appreciable gap in the sources remaining in the eleventh century. It is unclear whether this is simply an accident of preservation or whether Karkamish did in fact undergo a period of eclipse, possibly suffering under the territorial consolidation of a neighbouring power during that century, which will be discussed below. The sources from the earlier period appear to indicate the initial preservation of some kind of Hittite power. The question is whether Karkamish represents a kind of 'rump-state' left over from the Hittite Empire or whether it was weakened to the point of insignificance after its fall, before experiencing a political renaissance in the tenth century BC. ${ }^{31}$

It was long thought that Karkamish, the site of the Hittite vice-regent in northern Syria, was destroyed early in the twelfth century by 'sea-peoples' as well as by Aramaeans who emerge as a prominent population group also in this period. In fact, the archaeological evidence for a destruction of the site around 1200 is lacking: neither C. L. Woolley's excavations in 1911-14 and 1920 for the British Museum, nor those conducted by N. Marchetti of Bologna University since 2011, have found anything either to deny or confirm it, although the relevant Late Bronze Age levels had still not been reached in the 2012 season. The last known viceroy at Karkamish according to the archives of the Hittite capital in Hattusa was Talmi-Teššub, who referred to himself as 'King of Karkamish', by contrast to the Hittite emperor, who was referred to as 'Great King'. However, the discovery of a bulla with a royal seal-impression in hieroglyphic writing some twenty-five years ago at Lidar Höyük (see map) demonstrated that there was a 'King of Karkamish' called KuziTeššub, son of Talmi-Teššub. ${ }^{32}$ The implication is that, while the central authority in Hattusa had vanished sometime early in the twelfth century, the line of viceroys had survived its disappearance and was continuing an independent existence.

A little more light on what was going on comes from cuneiform texts discovered at the Middle Assyrian site of Tell Sabi Abyad on the Balih river, to the east of Karkamish.

${ }^{31}$ G. D. Summers, "Some implications of revised C14 and dendrochronological dating for the "Late Bronze levels" at Tille Höyük on the Euphrates', in Across the Border, ed. Yener (above n. 1) 317.

32 J. D. Hawkins, 'Kuzi-Tešub and the "Great Kings” of Karkamiš', Anatolian Studies 38 (1988) 99-108. 
Although as yet unpublished, the epigrapher responsible for publication has presented much of their contents. ${ }^{33}$ Assyrians used a method of dating by annual officials known as eponyms. While we have lists of these eponyms for earlier and later periods, the reconstruction of their order during this period can be tricky. One letter dated by the epigrapher to $1190 \mathrm{BC}$ speaks of problems between Karkamish and Emar, a city on the Middle Euphrates to the south of Karkamish, which had since been resolved. ${ }^{34}$ Another asks its recipient for information about the 'Land of Hatti', presumably referring to the central Anatolian Hattusa. It is dated to 1192 BC, thus showing that Hattusa still existed, or had only just been abandoned at this time ${ }^{35}$ Emar, which survived until its destruction in 1175 BC, would appear to have seceded from Hittite dominion for a short while just before 1190 $\mathrm{BC}$, as the evidence provided by cuneiform documents from there of a local rather than a Hittite filling the role of 'overseer of the land' might seem to suggest. ${ }^{36}$ The same 'overseer of the land' is mentioned in the Assyrian letter regarding the resolution of problems between Emar and Karkamish. At this point then, Emar seems to be acting on its own.

It is possible that we should attribute to this period the unprovenanced Ankara Silver Bowl with its hieroglyphic inscription. The Bowl was originally dated to the fifteenth century BC, because it appears to mention a Tudhaliya Labarna and his conquest of a country called Tarwiza-, thought to be the western land known from the campaigns of Tudhaliya I (c.1450) as Taruisa. ${ }^{37}$ A consensus is now growing on the basis of the developmental stage of the orthography and palaeography of the inscription, as well as historical considerations, that the Bowl must date to the post-Empire period, and come from the Karkamish region due to the mention of a specifically Karkamish god in the theophoric personal name of the king to whom the Bowl was dedicated (or made): (Maza)-Karhuha. ${ }^{38}$ If the reading of the name is correct, he could be one of the Tudhaliyas, listed as 'King' or 'Great King' in the tenth century inscriptions from Karkamish, to be discussed below, or their predecessor. Particularly interesting is the interpretation of the toponym Tarwiza- as an ethnic (Tarw-iza-), formed from the name of an enemy mentioned in some of the latest

\footnotetext{
${ }^{33}$ The documents are being prepared for publication by F. Wiggermann, but their content has been revealed by him in numerous presentations and is referred to in secondary literature.

${ }^{34}$ T96-1; see Y. Cohen and L. d'Alfonso, 'The duration of the Emar archives', in The city of Emar among the Late Bronze Age empires, history, landscape and society. Proceedings of the Konstanz Emar conference 25-26.04. 2006, ed. L. d'Alfonso, Y. Cohen, and D. Sürenhagen, Alter Orient und Altes Testament 349 (Münster 2008), 14-15.

${ }^{35}$ T93-12; Cohen and D'Alfonso, 'Duration' (n. 34 above) 15 n. 54, understood as an indication of the date of the destruction of Hattusa.

${ }^{36}$ Cohen and D'Alfonso, 'Duration' (n. 34 above) 15; Y. Cohen, "Abi-malik: the last "overseer of the land" in the city of Emar', in Looking at the ancient Near East and the Bible through the same eyes: a tribute to Aaron Skaist, ed. K. Abraham and J. Fleishman (Bethesda 2012) 13-27.

${ }^{37}$ J. D. Hawkins, 'A Hieroglyphic Luwian inscription on a silver bowl in the museum of Anatolian civilisations, Ankara', Studia Troica 15 (2005) 193-205. It has to be admitted that the decisive part of the name Tudhaliya cannot be seen due to being under a solder: MONS-[tu]. The title Labarna is a Late Bronze Age one reserved for the Hittite Great King (see below).

${ }^{38}$ C. Mora, 'Three metal bowls', in Vita, Festschrift in honour of Belkus Dinçol and Ali Dinçol, ed. M. Alparslan, M. Doğan-Alparslan, and H. Peker (Istanbul 2007) 515-21; Z. Simon, 'Die ANKARA-Silberschale und das Ende des hethitischen Reiches', Zeitschrift für Assyriologie 99/2 (2010) 247-69; S. Durnford, 'How old was the Ankara Silver Bowl when its inscriptions were added?', Anatolian Studies 60 (2010) 51-70.
} 
cuneiform tablets from Emar, normalized as Tarwa ${ }^{39}$ Emar was destroyed soon after these tablets were written. Who these people were remains a mystery, but the inscription may suggest that the otherwise unattested Tudhaliya (Labarna?) had defeated them, and that this was the occasion for dedicating the Bowl to a local king Maza-Karhuha, probably soon after the fall of the Hittite Empire. ${ }^{40}$ Maza-Karhuha must have been a king somewhere in the vicinity of Karkamish, if not Karkamish itself, but where Tudhaliya resided is unclear.

An inscription from Karahöyük-Elbistan, generally dated to the twelfth century, was erected by a local official and speaks of a visit by a 'Great King' Iri-Teššub. ${ }^{41}$ Who he is and where he ruled is unknown. Although Bryce suggested Karkamish, the location of the text suggests links with the area of Malatya further north (see map). ${ }^{42}$ The history of Malatya (Melid, in Neo-Assyrian texts) in the Early Iron Age has become a little clearer in recent years. Most important is the fact that one dynasty of kings of Malatya claimed descent from Kuzi-Teššub, 'King of Karkamish' (discussed above), two of the kings perhaps being his grandchildren, which means that their inscriptions must be dated into the late twelfth to early eleventh centuries, earlier than they had been. ${ }^{43}$ Malatya seems to have been linked to Karkamish in ways that are as yet unclear. ${ }^{44}$ It seems not to have been immediately affected by the collapse of the Hittite empire, nor to the same degree as the cities located along the Levantine coast. But new excavations at the site indicate that this relative stability came to an abrupt end in the early eleventh century, when Malatya was destroyed, only re-emerging as an important centre in the ninth to eighth centuries. ${ }^{45}$ A little more information can be gleaned from an Assyrian royal inscription dating to 1100: at this time, the Assyrian king Tiglath-pileser I encountered, quite possibly at Karkamish, a king of the 'land of Hatti' called, like his ancestor, Ini-Teššub; at the same time, the text notes that Malatya was under the rule of Allumari. ${ }^{46}$

During the eleventh century sources regarding Karkamish are virtually non-existent but it would be rash to conclude from this that a Hittite state based there had entirely disappeared. It may have been reduced to its immediately surrounding land by the end of the twelfth century, but once records resume it is striking how much cultural continuity can be observed. The next available information from Karkamish itself dates from the early tenth

${ }^{39}$ Mora, 'Three metal bowls' (n. 38 above) 519. See also Singer 'New evidence' (n. 17 above) 25; D. Arnaud, Textes syriens de l'Age du Bronze Récent, Aula Orientalis Supplementa 1 (Barcelona 1991) no. 25 and 44.

${ }^{40}$ Compare Simon, 'Silberschale' (n. 38 above).

${ }^{41}$ Hawkins, Corpus vol. I.1 (n. 4 above) 288-95.

${ }^{42}$ Epigraphic style and execution, however, may suggest a connection with the Anatolian plateau. See Hawkins, Corpus vol. I.1 (n. 4 above) 288.

${ }^{43}$ Hawkins, Corpus vol. I.I (n. 4 above) 285-87. The problem with this dating is that the word translated 'grandson' could also mean 'descendant'. See Hawkins Corpus vol. I.1 (n. 4 above) 302; Singer, 'Philistines in the north' (n. 6 above) 471.

${ }^{44}$ F. Giusfredi, Sources for a socio-economic history of the Neo-Hittite states, Texte der Hethiter 28 (Heidelberg 2010) 43.

${ }^{45}$ M. Liverani, 'Melid in the Early and Middle Iron Age: archaeology and history', in Ancient Near East, ed. Galil et alii (n. 1 above) 338-39, 343-44 for an attempt to place this archaeological periodization within the chronological framework known from contemporary Assyrian inscriptions.

${ }^{46}$ A. K. Grayson, Assyrian rulers of the early first millennium BC I (1114-859BC), Royal Inscriptions of Mesopotamia: Assyrian Periods, Vol. 2 (Toronto 1991) 37 (A.0.87.3, 28), $42-43$ (A.0.87.4, 30, 31). 
century BC. The earliest inscriptions known so far were erected by Suhi $\mathrm{I}^{47}$ who calls himself 'Country Lord', and by his son, who is referred to as 'the priest of Kubaba' as his name is not fully preserved. ${ }^{48}$ The texts honour a ruler called Uratarhunda, whose full title is 'Great King, King of Karkamish, son of Sapaziti, Great King, Hero. ${ }^{49}$ Both the title 'Country Lord', designating a fairly lowly official, and, of course, that of 'Great King' are known from the Hittite Empire, although the particular combination of titles here is new. ${ }^{50}$ Important to note is that the title 'Great King', originally exclusive to the Hittite king in Hattusa, was now applied to the ruler of Karkamish.

\begin{tabular}{|l|l|l|l|}
\hline $\begin{array}{l}\text { Karkamish } \\
\text { King }\end{array}$ & $\begin{array}{l}\text { (Karkamish) } \\
\text { Great King }\end{array}$ & $\begin{array}{l}\text { Karkamish } \\
\text { Country-Lord }\end{array}$ & Approximate date BC \\
\hline Kuzi-Teššub & & & early $12^{\text {th }}$ \\
\hline Maza-Karhuha? & Tudhaliya? & & early to mid-12 $^{\text {th }}$ \\
\hline & Iri-Teššub? & & mid-12 $^{\text {th }}$ ? \\
\hline & $\begin{array}{l}\text { Ini-Teššub (king of } \\
\text { Hatti)? }\end{array}$ & & 1100 \\
\hline & Sapaziti & & early $10^{\text {th }}$ \\
\hline & Uratarhunda & $\begin{array}{l}\text { Suhi I } \\
\text { Astuwalamanza }\end{array}$ & \\
\cline { 2 - 4 } & Tudhaliya & Suhi II & early $9^{\text {th }}$ \\
\hline & Grandsons of & Katuwa & \\
\hline & Uratarhunda & &
\end{tabular}

Table 1: Tentative reconstruction of the Early Iron Age dynasties at Karkamish

Suhi I appears to call himself the 'seed/kinsman(?)' of Uratarhunda, and we have evidence for a marriage between a king Tudhaliya and the daughter of Suhi I's grandson, the 'Country Lord' Suhi II. ${ }^{51}$ This and Suhi I's appellation may indicate that there was a history of intermarriage between the 'Country Lords' in Karkamish and its 'Great Kings'. Suhi I's great-grandson, the 'Country-Lord' Katuwa (late tenth to ninth century BC), seems to claim that the city had been 'empty' and that he had, according to the most recent interpretation of the verb, 'acquired it by a legal transaction' from the 'grandsons of Uratarhunda' ${ }^{52}$ After that the line of the 'Great Kings' and their title disappear entirely from the repertoire of titles at Karkamish. Are the grandsons of Uratarhunda really the very last of a dwindling Hittite ruling class of 'Great Kings', bought out of their birthright at Karkamish by a dynasty of

${ }^{47}$ A. Dinçol, B. Dinçol, J. D. Hawkins, and H. Peker, 'At the origins of the Suhi-Katuwa dynasty', Near Eastern Archaeology 75/3 (2012), 145 (excavated 2011).

${ }^{48}$ KARKAMIŠ A4b; Hawkins, Corpus vol. I.1 (n. 4 above) 80-82.

${ }^{49}$ Dinçol et alii, 'Suhi-Katuwa' (n. 47 above).

${ }^{50}$ J. D. Hawkins, “"Great Kings" and "Country Lords" at Malatya and Karkamiš', in Studio historiae ardens. Ancient Near Eastern studies presented to Philo H.J. Houwink ten Cate on the occasion of his 65th Birthday, ed. Th. van den Hout and J. de Roos, PIHANS 74 (Leiden 1995) 73-86.

${ }^{51}$ KELEKLİ; Hawkins, Corpus vol I.1 (n. 4 above) 93.

${ }^{52}$ KARKAMIŠ A11b+c §4; Hawkins, Corpus vol. I.1 (n. 4 above) 103. New interpretation at H. C. Melchert, 'Enclitic subject pronouns in Hieroglyphic Luvian', Aramazd, Armenian Journal of Near Eastern Studies 6/2 (2011) 75-77. The interpretation of the verb remains extremely tentative, and does not fit well with the immediate context of the text, which is reasonably clearly concerned with military achievements. 
'Country-Lord' administrators, or were the 'Great Kings' actually situated somewhere else by this time? It is difficult to say.

In addition to the information about the continued use of Hittite royal titulary at Karkamish, the contemporary inscriptions of Suhi I and his son refer to war with a neighbouring power:

A dispute arose for him with the land Sura (=Assyria?) and he opposed the army. To King Uratarhunda the mighty Storm-God and the goddess Kubaba gave a mighty courage $[\ldots]$ and he resolved the dispute. ${ }^{53}$

Who was the enemy? The eighth century Luwian-Phoenician bilingual inscription from Çineköy in Cilicia refers to a country called $s u+r a / i$, which the Phoenician parallel text gives as '̌r $r$, i.e. with initial aleph. ${ }^{54}$ That and the context make the identification $s u+r a / i$ with Assyria fairly secure. Assyrian power is usually thought to have been at a low ebb in the early tenth century, although the building inscription of an Assyrian official at Sadikanni on the Habur, dating from the reigns of Aššur-rabi II (1012-972) and Aššur-rēša-īši II (971$67)$, indicates that it maintained a fairly strong presence in the region east of Euphrates into the tenth century. ${ }^{55}$ So it seems likely that by the tenth century BC Karkamish was a political entity with the stature to engage, possibly successfully, with the resurgent power of Assyria. The following centuries of its history up until its annexation by Sargon II in 717 BC would be defined by this relationship.

At present, we have some, albeit hazy, information of developments at Karkamish in the twelfth and tenth century, with its history in the eleventh century a blank. ${ }^{56}$ This could, of course, be simply due to chance and new excavations may fill out the picture. What we can already see very clearly is: a) that Karkamish survived the disappearance of the imperial administration at Hattusa, b) that its dynasty of viceroys continued to govern, c) that it adopted the titles of its former overlord, and d) made use of the Luwian language and script that had developed in the Hittite centre as well as adopting at least one of the old Hittite royal names.

\footnotetext{
${ }^{53}$ Dinçol et alii, 'Suhi-Katuwa' (n. 47 above).

${ }^{54}$ ÇİNEKÖY Luwian $\S \S 6-7=$ Phoenician 8-9; Payne, Iron Age (n. 4 above) 43. An alternative interpretation is offered by Z. Simon, that this Sura refers instead to the area of Cappadocia in central Anatolia, where the central Hittite power would have continued its existence. Here a conflict between Karkamish and the old Anatolian Hittites would have been referred to. As long as the toponym Sura is not attested in any of the numerous inscriptions from this area, which is referred to as Tabal by the Neo-Assyrians, it is difficult to accept this hypothesis. Z. Simon, 'Where is the land of Sura of the Hieroglyphic Luwian inscription KARKAMIŠ A4b and why were Cappadocians called Syrians by Greeks?' Altorientalische Forschungen 39/1 (2012) 160-80.

55 A. K. Grayson, Assyrian rulers of the early first millennium BC (1114-859 BC). Royal Inscriptions of Mesopotamia, Assyrian Periods Vol. 2 (Toronto 1991) 126-27.

${ }^{56}$ One should also note the theory of F. Giusfredi, according to which there is one more generation to the SuhiKatuwa dynasty of the tenth to ninth centuries BC than previously assumed. This would extend our evidence for the dynasty further back, possibly even as far as the eleventh century BC. While this is one possible reading of the data, it remains a theory and will need further evidence to make it compelling. The motivation for the theory is the unlikelihood that competing dynasties of 'rulers' ('Kings' vs 'Country-Lords') would have survived at Karkamish for so long. This motivation is considerably defused by the peaceful interpretation of the changeover of power between the two referred to in n. 52 above. See Giusfredi, Sources (n. 44 above) 49-50.
} 


\section{The Land of W/Palistin in northern Syria: from philology to history?}

One of the most recent steps in the continuing decipherment of Hieroglyphic Luwian has been the recognition that two signs previously transliterated into the roman alphabet as $T A_{4}$ and $T A_{5}$, primarily because of the fact that they appeared in the word for 'place', which was thought to contain a dental consonant as it did in the Hittite word (peda-), are in fact clearly liquid or flapped consonants in every other word in which they occur. ${ }^{57}$ They originally expressed the phonetic values ali and ala respectively, although as time went by the second vowel-sound started to be used indiscriminately and the initial vowel was lost: la/i.

One immediate effect of this step in decipherment was the recognition that the placename previously read as Padasatini or Wadasatini on various inscriptions from northern Syria, and recognized as the Luwian term for the Amuq region, now needed to be read as or Palis(a)tini or Walis(a)tini. The further recognition on the basis of independent evidence that the sign used to write the sibilant ( $s \grave{a})$ is particularly used before stops, when the vowel is not to be indicated in the reading of the syllabic sign, leaves us with a place-name Palistin or Walistin. ${ }^{58}$ It is possible that the initial consonant, rendered alternately by a $/ \mathrm{p} /$ or by a $/ \mathrm{w} /$ in the Anatolian Hieroglyphic script, corresponded to the sound /f/, or started out as /p/, as in one older inscription, and was later lenited to $/ \mathrm{f} / .^{59}$

It immediately becomes clear that this name fits well with the group of people supposed to have settled, by whatever means, in southern Palestine, who are supposed eventually to have become the Philistines, and with the enemies of Egypt mentioned in the inscriptions of Ramesses III from Medinet Habu and the Papyrus Harris I. ${ }^{60}$ Furthermore, it is also difficult to exclude from consideration an association with the spread of Mycenaean-style pottery in the Amuq region, particularly locally made Late Helladic IIIC-style ceramics, in the early twelfth century BC, as well as some of the numerous city-destructions that occurred around that time and other factors associated, whether rightly or wrongly, with 'sea-people' activity. ${ }^{61}$ Reaction to this suggestion has ranged from enthusiastic to lukewarm. It is clear that the assessment of the evidence, especially of the ceramics and the typology of the citydestructions from the region (violent or non-violent, hostile or not), has a long way to go before the matter can be discussed in concrete terms. Furthermore, it is completely unclear how this kingdom is related to the Philistines of the southern Levant. ${ }^{62}$ We are concerned

57 J. D. Hawkins apud S. Herbordt, Die Prinzen-und-Beamtensiegel der hethitischen Grossreichszeit auf Tonbullen aus dem Nişantepe-Archiv in Hattusa, Mit Kommentaren zu den Siegelinschriften und Hieroglyphen von J. David Hawkins, Boğazköy-Hattuša 19, (Mainz am Rhein 2005) 289-90; E. Rieken and I. Yakubovich 'The new values of Luwian signs L 319 and L 172', in ipamati kistamati pari tumatimis. Luwian and Hittite studies presented to David Hawkins on the occasion of his $70^{\text {th }}$ birthday, ed. I. Singer (Tel Aviv 2010) 199-219.

${ }^{58}$ E. Rieken, 'Das Zeichen «sà) im Hieroglyphen-Luwischen', in Acts of the VII th international congress of Hittitology, Çorum, August 25-31, 2008, ed. A. Süel (Ankara 2010) 651-60.

${ }^{59}$ Singer, 'Philistines in the North' (n. 6 above) 463.

${ }^{60}$ J. D. Hawkins, 'Cilicia, the Amuq, and Aleppo. New light in a Dark Age', Near Eastern Archaeology 72 (2009), 171-72.

${ }^{61}$ On Amuq archaeology see K. A. Yener, ed., The Amuq valley regional projects, volume 1. Surveys in the plain of Antioch and Orontes delta, Turkey, 1995-2002 (Chicago 2005); B. Janeway, 'The nature and extent of Aegean contact at Tell Ta'yinat and vicinity in the Early Iron Age: evidence of the sea-peoples?' in Cyprus, ed. T. Harrison (above n. 2) 127-28.

${ }^{62}$ Note the caution urged at Singer, 'Philistine in the north' (above n. 6) 468 
here with the implications of these new readings and of new finds associated with them for Early Iron Age history.

It is conceivable that the Neo-Assyrian ethnic adjective for the kings of the Amuq region in northern Syria, Patinayya, was derived from this name. ${ }^{63}$ This scenario had already been envisaged before the new development in our understanding of the phonetic values of the hieroglyphic signs, and indeed before the discovery of the Aleppo temple inscription in 2003 furnished us with a spelling that showed initial $/ \mathrm{p} /$ rather than $/ \mathrm{w} / .^{64}$ The capital of the region of Unqi, over which the Patinayyan kings ruled, has now been securely located at Tell Tayinat, known to the Neo-Assyrians as Kinaliya/Kunuluwa ${ }^{65}$ From there a large statue, inscribed with an incomplete hieroglyphic text of a king Suppiluliuma, was recovered in 2012. Palaeography suggests a ninth century date for the inscription, which makes it possible that this Suppiluliuma is the Patinayyan Sapalulme encountered by the Assyrian king Shalmaneser III in 858 BC. ${ }^{66}$ Unfortunately the name of the polity ruled by this Suppiluliuma (II?) is not mentioned in the new hieroglyphic inscription, which is incomplete.

A fragmentary inscription found in Courtyard VIII at Tayinat in excavations conducted by the University of Chicago's 'Syro-Hittite Expedition' from 1935-38, mentions a Halparuntiya, previously identified with the Qalparunda encountered by the Assyrian king Shalmaneser III in 857 and $853 \mathrm{BC}$. This inscription also mentions the ethnic adjective walistiniza-, presumably associated with the name of the ruler, although there is no direct join to Halparuntiya's name. ${ }^{67}$ Style and orthography, however, indicate an earlier date (tenth to early ninth century) for these fragments than for the statue of Suppiluliuma (II?) from Tell Tayinat. ${ }^{68}$ The stratigraphy, i.e. the identification of the Building Phase these fragments belonged to, is unfortunately unclear. ${ }^{69}$

Further finds reinforce the assumption of an even earlier existence for the Walistinean land. Two stelae with parallel text inscriptions were recently recovered from Arsuz in the area south of the bay of Iskenderun. ${ }^{70}$ These are attributed to a Suppiluliuma son of Manana,

\footnotetext{
${ }^{63}$ Hawkins, 'Cilicia' (n. 60 above) 171-72.

${ }^{64}$ Sh. Yamada, The construction of the Assyrian Empire. A historical study of the inscriptions of Shalmaneser III (859-824 BC) relating to his campaigns to the west (Leiden - Boston 2000) $96 \mathrm{fn} .71$.

${ }^{65}$ See the copy of Assyrian king Esarhaddon's Succession Treaty with the 'Governor of Kunaliya' found at Tell Tayinat, J. Lauinger, 'Esarhaddon's Succession Treaty at Tell Tayinat: text and commentary', Journal of Cuneiform Studies 64 (2012) 91

${ }^{66}$ J. D. Hawkins, personal communication.

${ }^{67}$ TAYINAT 1 fragment 3-5, 1. 1; fragment 6; Hawkins, Corpus vol. I.2 (n. 4 above) 366.

${ }^{68}$ Particularly the orthographic feature of 'initial *a-final' is displayed by the fragments of TAYINAT 1 . For the dating of this phenomenon see H. C. Melchert, 'Spelling of initial /a-/ in Hieroglyphic Luwian', in ipamati kistamati pari tumatimis, ed. Singer (n. 57 above) 147. The inscriptions of the Suhi-Katuwa dynasty from Karkamish are similar in style.

${ }^{69}$ Information from current excavator T. J. Harrison of the University of Toronto by personal communication. Contrast statement at Singer, 'Philistines in the north' (above n. 6) 465.

${ }^{70}$ The stelae are kept in Hatay Archaeological Museum, where I was privileged to be able to view them in the autumn of 2009 together with the late Professor Ali Dinçol, along with Professor Belkıs Dinçol, to whom their publication had been entrusted. I am also profoundly grateful to both Professors Dinçol for allowing me to read through the inscription with themselves and David Hawkins in January 2010.
} 


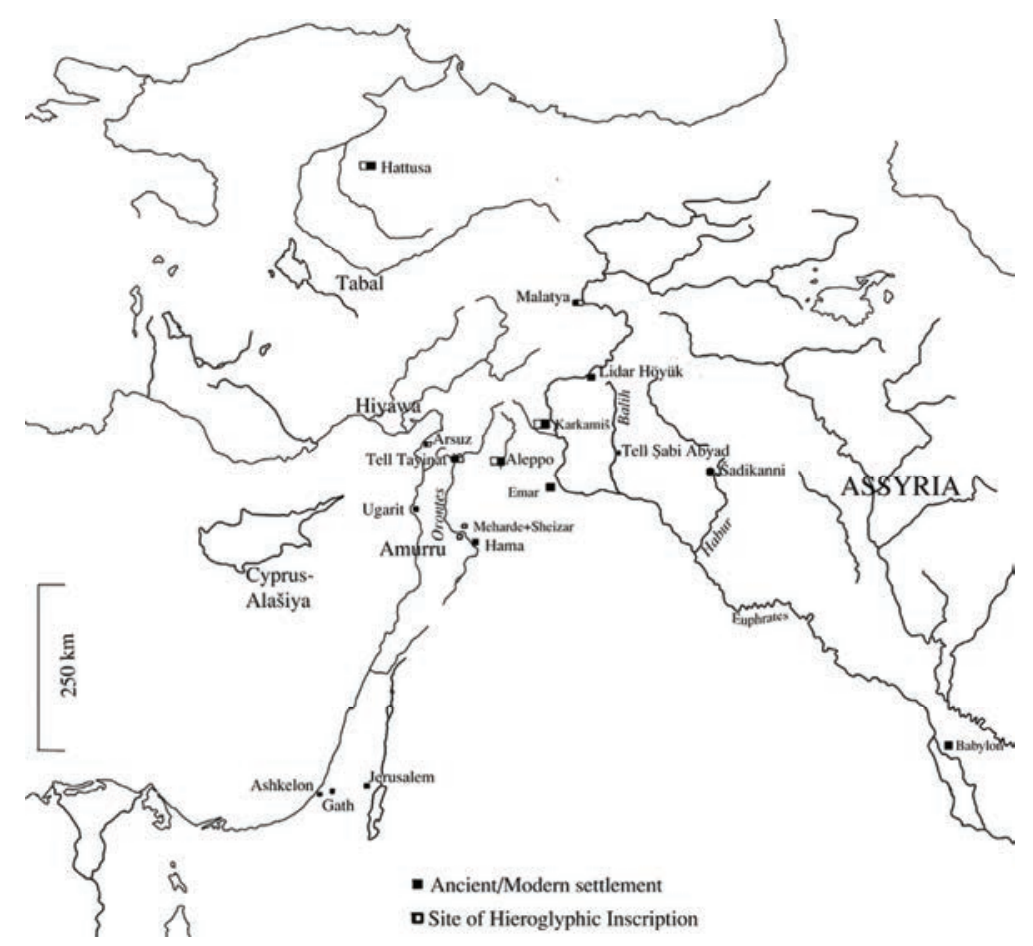

Fig. 1 Map of Eastern Mediterranean

who calls himself the Walistinean king. Palaeographic considerations and style of incision suggest comparisons with tenth century inscriptions from Karkamish, by contrast with the later statue of the Suppiluliuma recovered from Tell Tayinat, according to J. D. Hawkins. ${ }^{71}$

Already long known are the inscriptions from Meharde and Sheizar on the middle Orontes (see map), which also refer to a Walistinean king called Taita and his wife (or mother), Kupapiya. ${ }^{72}$ A king with the same name and a similar title also surfaced in an inscription excavated in 2003 on the citadel of Aleppo in the Temple of the Storm-God. Palaeographic and orthographic considerations have led J. D. Hawkins to suppose that the Taita from Aleppo was somewhat older than the Taita from Meharde and Sheizar, with the latter being possibly the grandson of the former. ${ }^{73}$

The Aleppo inscription is added to a figure of the king facing a figure of the Storm-God. The Storm-God figure has been supposed to date to the Late Bronze Age, whereas the figure of the king has been added later. ${ }^{74}$ It is difficult to date the inscription precisely, but a date

${ }^{71}$ J. D. Hawkins personal communication. Also reported at Strobel, 'Crucial $12^{\text {th }}$ century' (n. 14 above) 209; T. P. Harrison 'Tayinat in the Early Iron Age', in Across the border, ed. Yener (n. 1 above) 63.

${ }^{72}$ Hawkins, Corpus vol. I.2 (n. 4 above) 415-19.

${ }^{73}$ J. D. Hawkins, 'The inscriptions of the Aleppo temple', Anatolian Studies 61 (2011), 35-54; further discussion of dating: J. D. Hawkins, 'The usage of the Hieroglyphic Luwian sign "Crampon" (L. 386)', Kadmos 49 (2010), 8ff.; Strobel, 'Crucial 12 $2^{\text {th }}$ century' (n. 14 above) 209, 251 fn. 228; Singer, 'Philistines in the north' (n. 6 above) 463.

${ }^{74}$ Kohlmeyer, 'Building activities' (n. 3 above). 


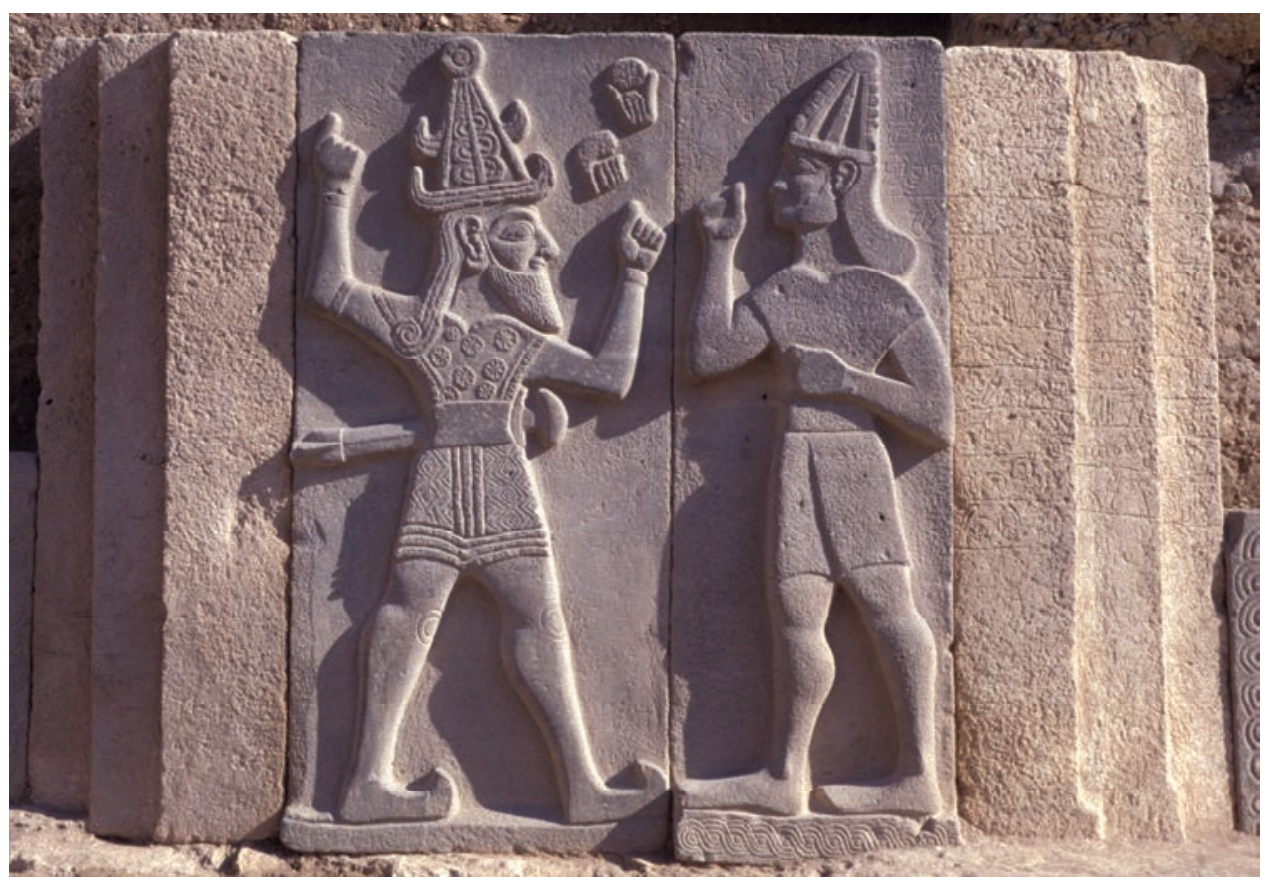

Fig. 2 Aleppo temple inscription of Taita I, photo courtesy K. Kohlmeyer

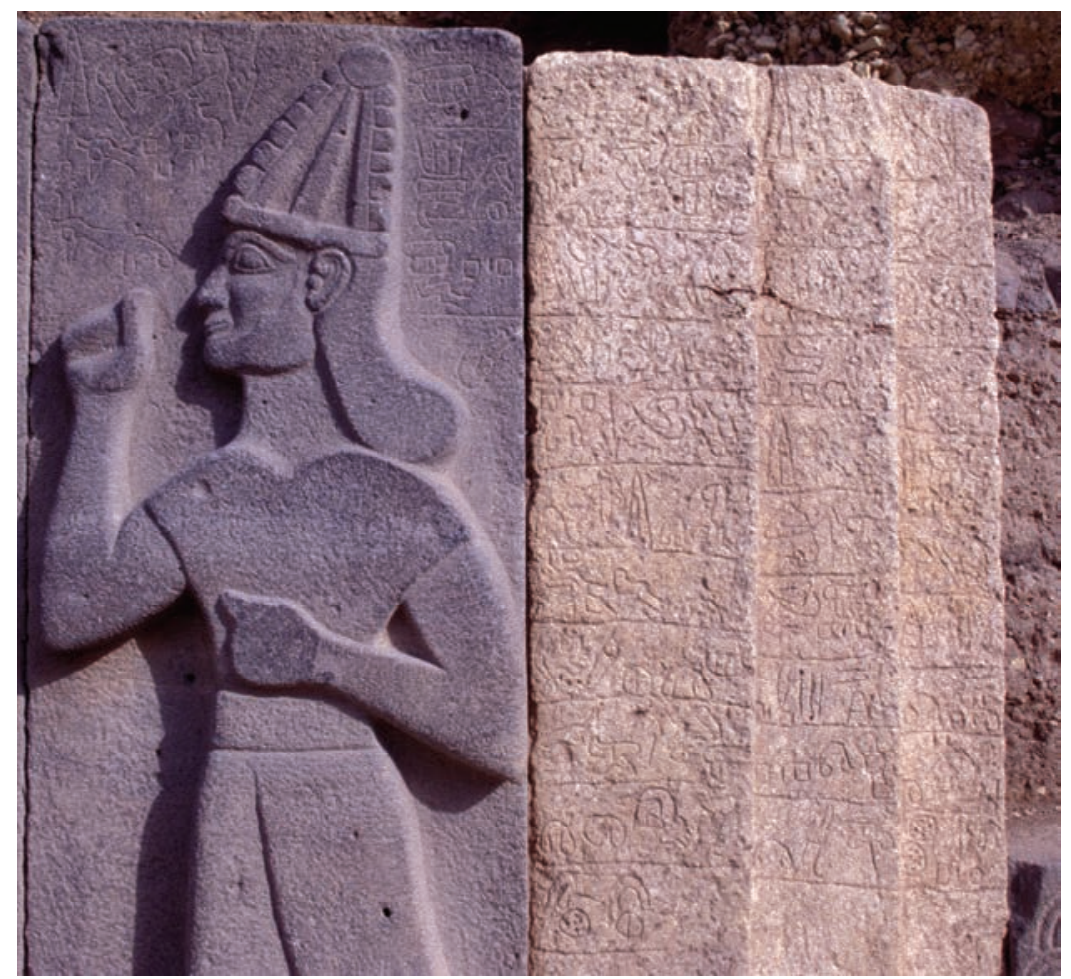

Fig. 3 Head of Taita I with Inscription, photo courtesy K. Kohlmeyer 
some time within the eleventh century may be correct on epigraphic grounds (palaeography and orthography), thus perhaps giving a tenth-century date for Taita from Meharde and Sheizar (see further below) ${ }^{75}$ Radiocarbon data from wooden beams that do not exclude the eleventh-century dating are also reported from the Aleppo temple. ${ }^{76}$ The Aleppo-temple context is a refurbishment dating to soon after the Late Bronze Age, entirely in Neo-Hittite monumental style, and incorporating elements, particularly a number of orthostats with reliefs that date from the Late Bronze Age Hittite period.

Clearly kings calling themselves Palistinean/Walistinean held sway over the major temple of northern Syria, where the Hittite king Suppiluliuma I had installed his son Telipinu in the late fourteenth century BC, around 150 years or so before the collapse of the Hittite Empire. Whether this was a coherent kingdom exerting influence down as far as the region of Hama, near where the Meharde inscription is supposed to have been found, or whether these were ephemeral extensions of influence at different points in time cannot yet be ascertained for certain. If we integrate these kings into the roster of kings of Patin already known from Neo-Assyrian annals, particularly those of Assurnașirpal II (883-59 BC) and Shalmaneser III (858-24 BC), the attested kings from this area look like this, although the order remains highly speculative:

\begin{tabular}{|l|l|l|l|}
\hline Known from HL & Inscription & Known from Assyrian Annals & Date \\
\hline Taita I & Aleppo 6-7 & & $11^{\text {th }}$ century BC \\
\hline Taita II & Meharde+Sheizar & & $10^{\text {th }}$ century BC \\
\hline Manana & Arsuz 1+2 & & $10^{\text {th }}$ century BC \\
\hline Suppiluliuma I & Arsuz 1+2 & & $10^{\text {th }}$ century BC \\
\hline Halparuntiya I? & Tell Tayinat I & Lubarna I? & $10^{\text {th }}$ century BC? \\
\hline & & Sapalalme (+Lubarna I?) & c. 875?, 858 BC \\
\hline Suppiluliuma II & New Tell Tayinat & Qalparunda II BC \\
\hline & & Lubarna II & 857 BC \\
\hline & & 829 BC \\
\hline
\end{tabular}

Table 2: Kings of Patin/Palistin in Luwian and Assyrian sources

Lubarna I, encountered by both Assurnașirpal II and Shalmaneser III, may be a mistake, a confusion arising from the use of the name Labarna (as in the Late Bronze Age) as a title for Suppiluliuma/Sapalulme. ${ }^{77}$ Otherwise we have to consider that this Sapalulme, who may be identical with the Suppiluliuma of whom a monumental statue with details of his campaigns and activities has recently been found at Tayinat (see above), was only a vice- or co-regent or a very temporary ruler. ${ }^{78}$ This seems unlikely in view of this new inscriptional

\footnotetext{
${ }^{75}$ I. Singer, 'Philistines in the north' (n. 6 above) 471, correctly urged caution in using the dating arrived at by these means as a secure basis for historical reconstruction.

${ }^{76}$ Kohlmeyer, 'Building activities' (n. 3 above) 276 fig. 10.

77 A. Fuchs already suggests the name is in fact a title at H. D. Baker, ed., The prosopography of the Neo-Assyrian Empire volume 2. Part I: H-K., The Neo-Assyrian Text-Corpus Project (Helsinki 2000) 667. See however Giusfredi, Sources (n. 44 above) 54 fn. 80.

${ }^{78} \mathrm{~J}$. D. Hawkins points out to me that the stone slab inscription of Shalmaneser III from the temple of Nabû in Kalhu (modern Nimrud) refers to a Lubarna in 858 BC after previously mentioning Sapalulme: A. K. Grayson,
} 


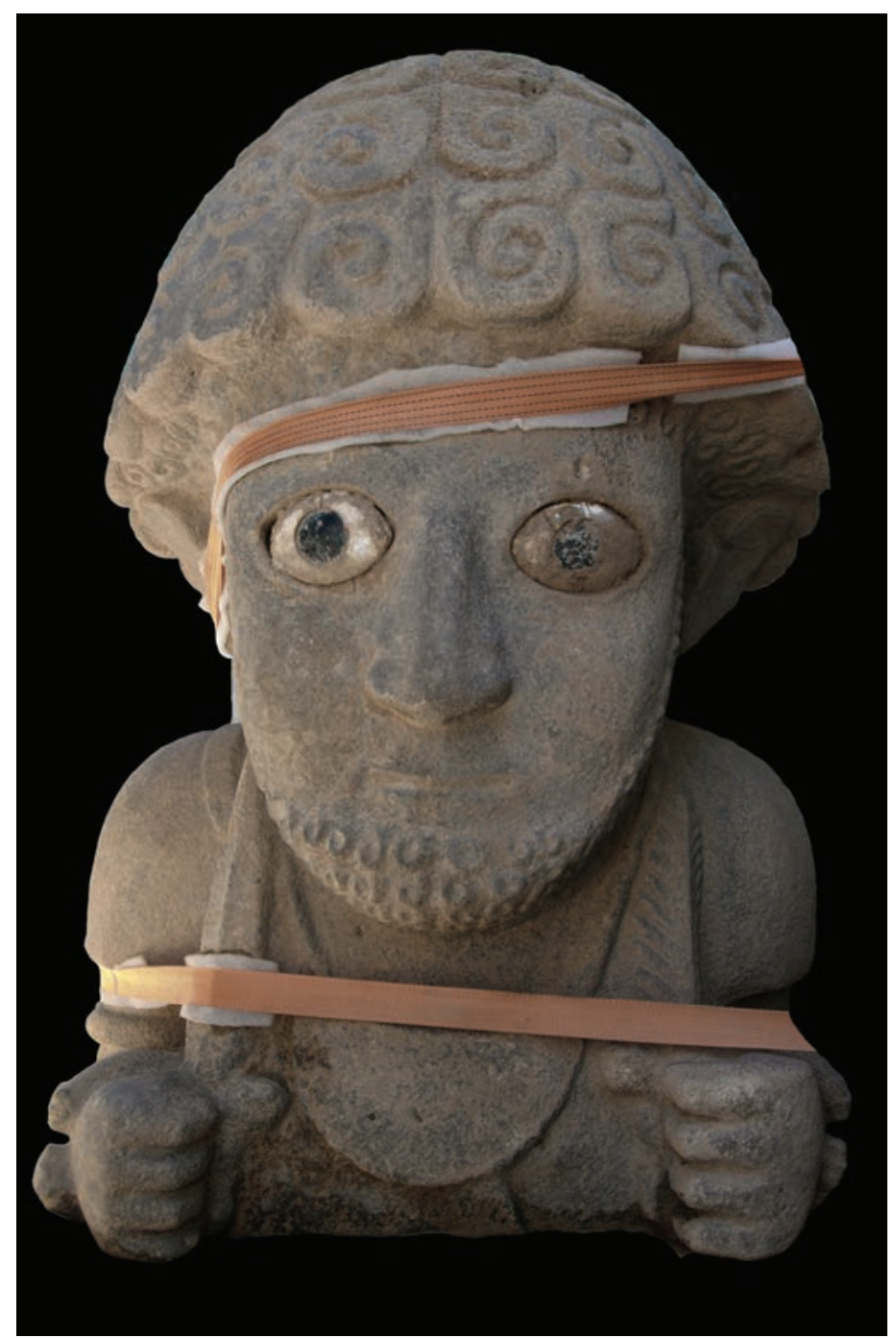

Fig. 4 Suppiluliuma (II?) from Tell Tayinat (photo Jennifer Jackson)

evidence from the capital of the land of Palistin, providing the two rulers are in fact the same in both Luwian and Assyrian documents. Thus we would have some evidence for a further Hittite title (Labarna) being continued in this kingdom right into the ninth century BC, although there is no other such evidence. Note that the proposed identity of the new Suppiluliuma (II?) with Sapalulme is the only incidence of a synchronism between Assyrian and local documentation that we have for the region.

Assyrian rulers of the early first millennium BC II (858-745 BC), Royal Inscriptions of Mesopotamia: Assyrian Periods Vol. 3 (Toronto 1996) A.0.102.3, 95; Sapalulme the Patinean mentioned at A.0.102.2, 52. Again, either this is a co-regency, or he is talking about the same person (Sapalulme) using a title. The Kurkh monolith (1. 52) and the stone slab from Kalhu talk about 'Alimush the fortified city of Sapalulme the Patinean', but only the stone slab (1. 94-5) talks about 'Urime the fortified city of Lubarna the Patinean'. 


\section{International contacts of the land of Palistin}

Taita I in Aleppo 7 even seems to have been in contact with Egypt, although the context is fragmentary and it is unclear what he is doing. ${ }^{79}$ This might indicate that even at this earliest stage of the current attestation of the name Palistin, the political entity denoted by it entertained international diplomatic or military relations over an extensive area, not thought to be usual for this period (eleventh century BC) in this region (northern Syria down to Egypt). ${ }^{80}$ The only indication of official Egyptian contacts abroad during this period known to me is a lapis bead from the collar of pharaoh Psusennes I, which is dedicated to an Assyrian wife of his, daughter of the Grand Vizier of Assyria. ${ }^{81}$

The immediate context of the mention of Egypt is damaged. The narrator has done something 'from Karkamish' either 'from the bedroom' or 'from the storehouse' (ALEPPO 7 2, §2), after which a $\operatorname{god}(\mathrm{dess})(\mathrm{Ku}[\mathrm{baba}])$ is mentioned $(2 \S 3) .^{82}$ Then there is a conditional 'if a scribe ...' $(4, \S 6)$. Possibly this scribe is identical with the subject of the verb in the next clause '... he/they brought (an) equid(s) of the land of Egypt [to me?]' (5, $\S 7)$. That the scribe is the subject of the action is supported by the fact that the same scribe, 'that scribe', is mentioned later in the narrative $(8, \S 13)$.

Given that the inscription is in a temple, in this case across a lion dated by the excavator to the Early Iron Age and a sphinx dated by him to the Late Bronze Age, it might be reasonable to infer that we are either dealing with a transport of a divine statue (of Kubaba?) from her cella ('bedroom') in Karkamish, although it should be noted that the deity is only mentioned in the clause after the mention of the city, or with a journey made by the king from the cella of the goddess in Karkamish. Possibly Egyptian equids (mules?) ${ }^{83}$ were used for either of these purposes. The passage under these interpretations does not have to indicate Palistinean hegemony over Karkamish, but it remains unclear what is going on. ${ }^{84}$ This explanation of the damaged text may, however, indicate hegemony over a supraregional religious institution, the temple of the Storm-God at Aleppo, that different northSyrian polities all participate in. This can of course be a reflection of political circumstances, but does not necessarily support the notion of an imperial entity engaged in long-distance

\footnotetext{
${ }^{79}$ ALEPPO 7, 5 §7; Hawkins, 'Aleppo temple’ (n. 73 above) 48.

${ }^{80}$ Note however the comments of S. Laemmel on continuing international trade in this period, with regard to grave pottery assemblages from Tell el-Far'ah in southern Palestine: S. Laemmel, 'A note on the material from the Late Bronze and Early Iron Age cemeteries from Tell el-Far'ah South', in Forces of Transformation, ed. Bachhuber and Roberts (n. 1 above) 184.

${ }^{81}$ K. A. Kitchen, The Third Intermediate Period in Egypt (1100-650 BC) 3rd edn (Oxford 1996) 233

${ }^{82}$ The verb (S1 pret.) pa-za-i(a)-ha may be related to the known verb $\left(\mathrm{PES}_{2}\right) p a-z a$ - which is interpreted as 'go' by J. D. Hawkins, 'Aleppo temple' (n. 73 above) 49, see Hawkins, Corpus vol. I.1 (n. 4 above) 185 for attestations, or as 'allocate' by H. C. Melchert, 'A Luwian dedication', in Indo-European perspectives, studies in honour of Anna Morpurgo Davies, ed. J. H. W. Penney (Oxford 2004) 375-78. If so it has an irregular further suffix -ia-, or an irregular ending in -aiha. The allegedly related verb is spelled regularly in SHEIZAR §2: $\left(\mathrm{PES}_{2}\right) p a-z a-h a_{\mathrm{x}}$ (Hawkins (n. 4 above) 417). Either this is not the same verb, or we have analysed the imperfective (-za-) in $\left(\mathrm{PES}_{2}\right) p a-z a$ - wrongly in the first place.

${ }^{83}$ For discussion of the equid represented by this extremely problematic hieroglyphic sign see Hawkins apud Herbordt, Prinzen (n. 57 above) 295-96.

${ }^{84}$ Hegemony over Karkamish is tentatively suggested at Hawkins, ‘Aleppo temple’ (n. 73 above) 53.
} 
trade or other intensive diplomatic activities with Egypt. It does at any rate seem to indicate high-level contacts with Egypt of a type that are not considered usual at this period.

Geographically somewhat closer to home and geo-politically more transparent would be an alleged contact with the kingdom of Judah. C. Steitler has argued that king Taita of Walistin is identical with the Biblical Toi of Hamath, king David's ally against the Aramaean Hadadezer of Zobah (II Sam. 8, 9-10; I Chron. 18, 9-10) ${ }^{85}$ Toi sends his son to David with gifts of precious metals after Hadadezer is defeated, as he had also fought wars against the Aramaean. Should this equation be correct, the implications for the debate concerning the early monarchy of Judah and the extent of the state ruled by David in the tenth century BC are far reaching. Much of the Biblical narrative concerning David's wars against Aram has been supposed by some scholars to have been invented in or after the eighth century BC, when similar enemies presented themselves as a model for projecting an epic tale of Judean nation-building back into an earlier period, largely using or appropriating the exploits of the ninth century Omride dynasty in the north. ${ }^{86}$ Corroboration of the existence of an ally in these early campaigns would not only shore up the Biblical narrative at an important juncture, but also provide evidence for the international standing of the state of Judah in the tenth century BC. If this is so, the king would have to be Taita II, known from the Meharde and Sheizar inscriptions.

Possible objections to the equation include the designation of the kingdom of Toi in the Bible. If Taita II was a Walistinean king, and the Bible knows the word we translate as Philistine only too well (300 attestations), why is he called king of Hamath? This may well have internal motivations. David's typically ambiguous relationship with the Philistines in the south might have prompted the choice of a different place-name for the official record. ${ }^{87}$ Or it might just be the case that the Judeans did not know about or found it irrelevant to mention the parts of Toi's kingdom further to the north. Another possibility is that the term Walistinean did not have an ethnic or regional connotation after all. Whatever we conclude from this, we should follow the advice of I. Singer in this matter and guard against constructing new historical paradigms too hastily based on our current understanding of this new evidence. ${ }^{88}$ In a few years the evidence may all look very different. Control of the region around Hama did not last through the ninth century, however, if we can take the Meharde and Sheizar stelae as evidence of such control in the first place. Clearly by the time we reach the Assyrian king Shalmaneser III in the mid-ninth century BC, Hamath is under the control of a powerful local dynasty led by Urhilina, who appears in the Assyrian record as Irhuleni.

${ }^{85}$ C. Steitler, 'The Biblical Toi of Hamath and the Late Hittite State "P/Walis(a)tin"', Biblische Notizen 126 (2010) 81-99; see already A. Mazar, 'The search for David and Solomon: an archaeological perspective', in I. Finkelstein and A. Mazar, The quest for the historical Israel. Debating archaeology and the history of early Israel (Leiden-Boston 2007) 137-38. More generally: B. Sass, 'Four notes on Taita King of Palistin with an excursus on King Solomon's empire', Tel Aviv 37 (2010), 169-74.

${ }^{86}$ N. Na'aman, 'Hazael of 'Amqi and Hadadezer of Beth-rehob', Ugaritforschungen 27 (1995), 381-94; I. Finkelstein, 'Hazor and the north in the Iron Age: a low chronology perspective', BASO 314 (1999) 60.

${ }^{87}$ W. Dietrich, 'David and the Philistines: literature and history', in Ancient Near East, ed. Galil et alii (n. 6 above) 79-98.

${ }^{88}$ I. Singer, 'Philistines in the north' (n. 6 above) 456. 
To the northwest, across the Amanus mountains and into plain Cilicia, foreign policy appears to have been dictated by conflict with the neighbours in Hiyawa, the local name for Assyrian Que, according to the new stelae from Arsuz from the tenth century BC. ${ }^{89}$ The contours of such a conflict are as yet unclear. However, that conflict existed indicates how the kingdom of Walistin was a force to be reckoned with in territorial disputes from the Bay of İskenderun through the Amuq down to the region of Hama, at least in the tenth century. It is quite likely that it still had control as far east as Aleppo at this stage, if its eleventh-century hegemony over the Temple of the Storm-God can be used as evidence.

\section{The persistence of an imperial idiom}

Although much is still unclear, excavations at Tell Tayinat reveal a brief period of habitation, Iron Age Field Phases 6-3, at the beginning of the Iron Age that was characterized by low-level agricultural installations, pits, and silos, and a lack of monumental architecture, which mirrors a similar four-phase sequence at other sites in the Amuq. ${ }^{90}$ This was also the period during which locally made Late Helladic IIIC-style pottery began to appear at the site in large quantities, as in the rest of the Amuq region. Although the assessment of the ceramic development at Tayinat is not yet complete, by the time the first Building Phase (tenth century BC) brings a return to monumental architecture this type of pottery is supposed to be eclipsed by Red-Slipped Burnished Ware. ${ }^{91}$

I. Singer has suggested that we keep the possible migrants who may or may not have brought the name Palistin to northern Syria separate from the kingdom that arises in the eleventh century BC. ${ }^{92}$ How believable this is depends on our assessment of the level of migration, but it would currently appear that any migrants were wholly assimilated into the local material culture within a century or so, leaving only their name behind. If the etymological comparison of the kingdom of Palistin with the peleset of Ramesses III and the Philistines of the southern Levant has any substance, by the time of the first king Taita the name would have been all that they had in common. ${ }^{93}$

Once a more prosperous economic situation had developed, as evidenced by a return to a monumental architectural building style, it is the Hittite imperial idiom, as exemplified by display inscriptions in Hieroglyphic Luwian that the wealthy and powerful turned to in order

\footnotetext{
${ }^{89}$ Reported by Strobel in 'Crucial $12^{\text {th }}$ century' (n. 14 above) 209; Harrison, 'Tayınat in the Early Iron Age' (n. 71 above) 63 .

${ }^{90}$ T. P. Harrison, 'The Late Bronze/Early Iron Age transition in the North Orontes Valley', in Societies in transition. Evolutionary processes in the Northern Levant between Late Bronze Age II and Early Iron Age, ed. F. Venturi (Bologna 2010) 87-88. Iron Age Field Phase 5 has produced a radiocarbon date of $1115 \mathrm{BC} \pm 50$, T. P. Harrison, 'Tayınat in the Early Iron Age' (n. 71 above) 65.

${ }^{91}$ Janeway, 'Aegean contact' (n. 61 above) 137; T. P. Harrison, 'Tayinat in the Early Iron Age' (n. 71 above) 67.

${ }^{92}$ Singer, 'Philistines in the north' (n. 6 above).

${ }^{93}$ It is difficult to argue with D. Kahn, 'Campaign of Ramesses' (n. 21 above) 5, that a 'Land of Palestine' was established already in the early twelfth century BC in the Amuq and would have been the peleset enemy fought by Ramesses III. The earliest radiocarbon dates for the Iron Age at Tayinat (Field 1, Field Phase 5, n. 90 above) are rather from the end of the twelfth century.
} 
to express their hegemony, and this already in the eleventh century BC in Aleppo at least. ${ }^{94}$ In Karkamish it appears that Hittite imperial power continued in some form, gradually metamorphosing into the form in which we meet it in the later Iron Age, initially continuing the same dynasty and using the same titulary as during the Late Bronze Age Hittite Empire. It is possible, but unproven in my view, that Karkamish, along with Malatya, suffered some contraction in the eleventh century BC while the kingdom of Palistin was developing. Essentially, however, it is striking how quickly a return to polities consisting of influence at the least over substantial territories was possible, particularly in the case of Palistin, which potentially inherited the structure of Late Bronze Age Hittite imperial control in the area of the Amuq plain and northern Orontes valley. ${ }^{95}$ Here international contacts, possibly even of a type known from the Late Bronze Age, are also included in the constellation. This is not the chaotic fragmentation that the model of an end of Empire due to mass immigration and inter-ethnic conflict might suggest. Future finds may well demonstrate that the so-called Dark Age was not so gloomy after all.

SOAS, University of London

\footnotetext{
${ }^{94}$ Given the current but provisional dating of the Building Level One at Tayinat to the tenth century, one must await further evidence to establish whether Taita I of the Aleppo Temple inscriptions was also established there or somewhere else.

95 T. P. Harrison, 'Tayinat in the Early Iron Age' (n. 71 above) 64.
} 
This BICS contains

Mark Weeden After the Hittites: the kingdoms of Karkamish and Palistin in northern Syria

Lindsay Allen The letter as object: on the experience of Achaemenid letters

S. C. Todd Male slave sexuality and the absence of moral panic in Classical Athens

Hugh Bowden On kissing and making up: court protocol and historiography in Alexander the Great's 'experiment with proskynesis'

Alan Griffiths Where did early Roman history come from?

John Noël Dillon The delegation of the xviri to Enna ca. 133 BC and the murder of Tiberius Gracchus

Yulia Ustinova To live in joy and die with hope: experiential aspects of ancient Greek mystery rites

The next issue, BICS-57-1, will be a general issue

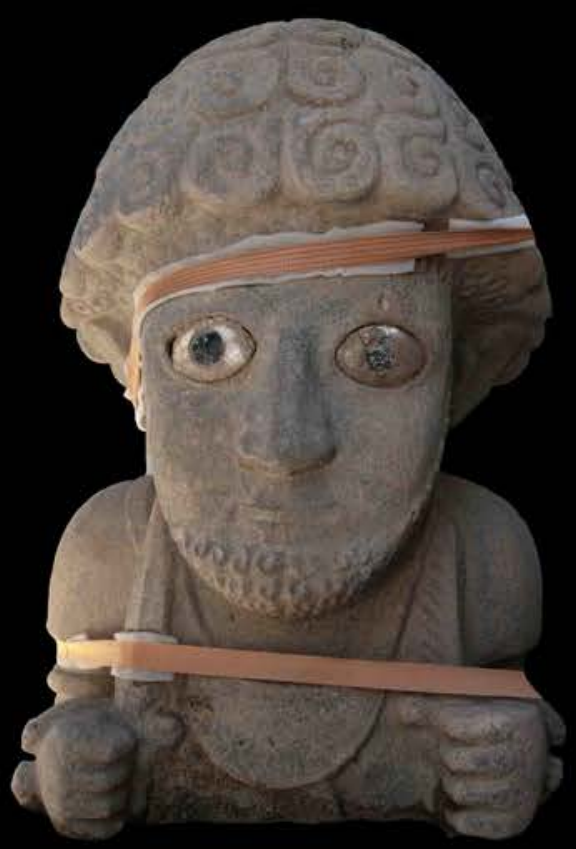

The cover image shows Suppiluliuma (II?) from Tell Tayinat.

See Mark Weeden's article in this issue, 'After the Hittites: the kingdoms of Karkamish and Palistin in northern Syria', at p. 16.

Photo Jennifer Jackson

(C) Jennifer Jackson 2103. All rights reserved. 